\title{
Physical properties of heavy liquid-metal coolants in a wide temperature range
}

\author{
Pjotr Popel $^{1}$, Sergey Stankus ${ }^{2}$, Alexandre Mozgovoy ${ }^{3}$, Rashid Khairulin ${ }^{2}$, Michail Pokrasin ${ }^{4}$, Denis Yagodin ${ }^{1}$, Natalja \\ Konstantinova $^{1}$, Alexandre Borisenko ${ }^{1}$ and Mikhail Guzachev ${ }^{1}$ \\ ${ }^{1}$ Institute of Physics and Technology, Ural State Pedagogical University, 26 Cosmonavtov ave., Ekaterinburg, 620219, \\ Russia, e-mail: pspopel@mail.ru \\ ${ }^{2}$ Kutateladze Institute of Thermophysics, Siberian Division of the Russian Academy of Sciences, 1 Lavrent'ev ave., \\ Novosibirsk, 630090, Russia, e-mail: stankus@itp.nsc.ru \\ ${ }^{3}$ Joint Institute for High Temperatures, Russian Academy of Sciences, 13/2 Izhorskaya st., Moscow, 125412, Russia, e- \\ mail: mozgovoy@ihed.ras.ru \\ ${ }^{4}$ Baikov Institute of Metallurgy and Materials Studies, Russian Academy of Sciences, Moscow, 117334 Russia.
}

\begin{abstract}
The pulse-phase method, the gamma-attenuation method and the method of dumping oscillation of a crucible with a melt were used for measuring the velocity of sound, the density and the kinematic viscosity of a set of liquid-metal coolants for perspective nuclear reactors. There are liquid gallium, indium, tin, lead, bismuth and lead-bismuth eutectic alloy among the melts investigated. The accuracy of the measurements was as high as $0.3 \%, 0.2$ to $0.4 \%$ and $1.5 \%$ for the ultrasound velocity, the density and the viscosity, correspondingly.
\end{abstract}

\section{Introduction}

The basic principles of the strategy of development of the Russian nuclear power industry for the period until 2050 are presently being elaborated by Rosatom RF (State Corporation for Atomic Energy of the Russian Federation). And the road map for innovative development of the Russian nuclear power industry in the first half of the XXI century is being prepared by the Russian Academy of Sciences. In accordance with these basic documents, much importance in the overall structure of the country's power industry is attached to the fast nuclear reactors with liquid-metal coolants in their primary circuit. It is planned to develop and construct several fast reactor units of the $\mathrm{BN}-800$ and BREST-300 types with sodium and lead coolants, respectively, and replace water-moderated water-cooled thermal reactors of the VVER-440 type (which exhausted their operating resource and are being removed out of service) by monoblock fast reactors of the SVBR 75/100 type with lead-bismuth coolant.

Therefore, the experimental investigation of the thermophysical properties of heavy liquid-metal coolants (HLMC) such as gallium, indium, tin, lead, bismuth and reciprocal binary lead-bismuth alloy of eutectic composition $(44.5 \%$ by mass $\mathrm{Pb}+55.5 \%$ by mass $\mathrm{Bi}$ [1]), the melting temperature of which is 398.1 $\mathrm{K}$ according to the International Temperature Scale of 1990 (ITS-90) [2], and the production on their basis of recommended reference data are of great interest to designers and manufacturers of fast breeder reactors. In so doing, the most informative properties are the velocity of sound, the density and the viscosity in the condensed phase. Indeed, the velocity of sound in liquid-metal coolants may be used for calculating their hard to experimentally determine isothermal compressibility and heat capacity ratio at constant pressure and volume in the molten state. The density values, together with the viscosity of the melts are important to calculate hydrodynamic regimes of coolants flows inside the reactors.

However, these properties for liquid HLMC are still inadequately studied; references to them are either completely absent from recent reference publications [3] or are very few [4]. Therefore, for the purpose of compiling more accurate and reliable reference data on the above mentioned properties of the molten HLMC, we investigated their temperature dependencies in wide ranges above the melting temperatures. 


\section{Measurement procedure experimental setups}

and

\subsection{Ultrasound velocity measurements}

The velocity of sound in metal melts was investigated by the pulse-phase method in an experimental setup; the schematic diagram, the measuring cell, and the structure of this setup are given in Figs. 1 and 2.

This measuring method is absolute, because it does not require any pre-calibration. It is based on determining the wavelength $\lambda$ and sound frequency $f$, with the velocity of sound calculated by the following formula:

$a=\lambda f$

A G5-72 generator generated square electric signals with a duration of 1 to $5 \mu$ s and repetition rate of 2 $\mathrm{kHz}$; these signals in turn shaped radio pulses of high-frequency $(f=33.83 \mathrm{MHz})$ sine voltage from a G4-151 generator with a built-in synchronizing frequency meter. These pulses, the amplitude of which could be smoothly regulated from zero to 1.2 $\mathrm{V}$, were delivered to lower radiating piezoelectric elements of the measuring and reference cells of one and the same structure connected in parallel with one another. In so doing, the working cell was filled with metal melt under investigation and the reference cell with distilled water.

Sounding signals in the form of acoustic pulses passed through elements of the measuring and reference cells and arrived at their upper receiving piezoelectric elements where they were reconverted to electric pulses. Because the delay times of acoustic signals in both cells were fitted to be approximately the same, the electric pulses at their outlets transmitted via coupling circuit interfered with one another. The results of this interference were amplified in a selective receiver and observed on the screen of an S1-70 oscilloscope.

The upper sound duct of the measuring cell could be displaced along its vertical axis. The duct displacement was measured by a digital micrometer graduated to $0.001 \mathrm{~mm}$. In so doing, the oscilloscope registered the sequence of extreme of interference signals, the distances between which were equal to the sound wavelength. This wavelength may be calculated by the formula

$\lambda=\Delta h / n$,

where $n$ is the number of minima of acoustic vibrations, which appeared on the screen of oscilloscope upon displacement of the upper sound duct of the measuring cell through $\Delta \mathrm{h}$, and the velocity of sound in the liquid under investigation is, in view of relations (1) and (2),

$a=(\Delta h / n) f$. (a)

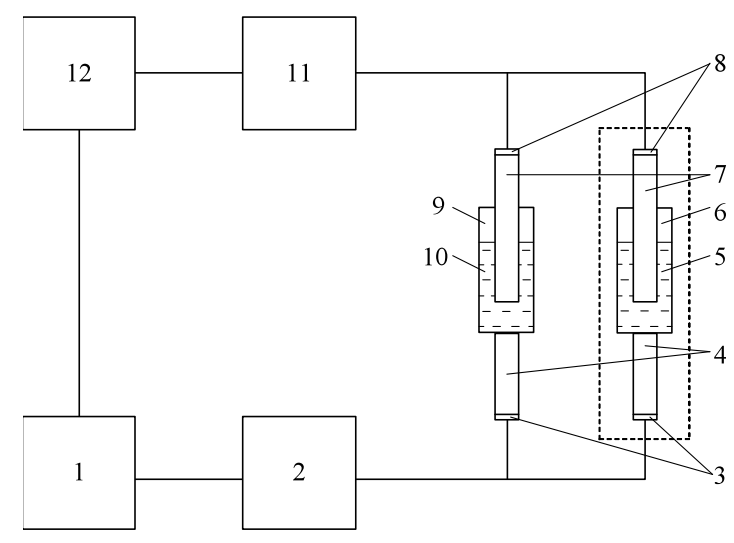

(b)

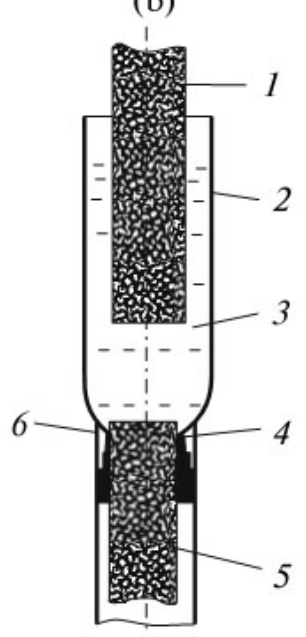

Fig. 1. The experimental setup tor measuring the sound velocity in metal melts; (a) schematic diagram of the experimental setup: (1) pulsed signal generator, (2) sine signal generator, $(3,8)$ piezoelectric elements, $(4,9)$ sound ducts, $(5)$ liquid metal under investigation, (6) container for metal melt, (7) heating furnace, (10) container for reference liquid, (11) reference liquid, (12) selective amplifier, (13) oscilloscope; (b) measuring cell: (1) upper sound duct, (2) container for liquid metal, (3) metal melt, $(4,6)$ thermocouples, (5) lower sound duct.

The carrier frequency $f$ of acoustic vibrations equal to 33.83 $\mathrm{MHz}$ was measured by an electronic frequency meter with an absolute error of $\pm 50 \mathrm{~Hz}$, which amounts to approximately $\pm 2 \cdot 10^{-4} \%$ in relative units. Therefore, in order to improve the accuracy of experiments, it is necessary to increase the number of registered minima of sound wave, i.e., to expand the acoustic base of these measurements.

Fused quartz was used as the material for the basic elements of the measuring and reference cells, including their lower and upper sound ducts. Lead zirconatetitanate in the form of round plates 5 to $10 \mathrm{~mm}$ in diameter and 0.3 to $0.7 \mathrm{~mm}$ thick was used for the radiating and receiving piezoelectric transducers. This ceramic exhibits the best electromechanical properties among other materials of this kind. It is characterized by wider resonance absorption bands and lower excitation voltage compared to quartz piezoelectric elements. For example, rather powerful acoustic vibrations are excited 
in this ceramic with the amplitude of input electric pulses exceeding $0.5 \mathrm{~V}$.

It is known [5] that the condition $D / X>30$, where $D$ is the diameter of sound radiators and detectors, must be observed for reducing the error of acoustic measurements due to diffraction effects. Based on process consideration, the diameter of sound ducts of $14 \mathrm{~mm}$ was selected: this fully satisfied the foregoing condition. This diameter defined the diameter of the measuring and reference cells (20 to $25 \mathrm{~mm}$ ) and the inside diameter of tube heating furnace $(>30 \mathrm{~mm})$. With the furnace length of about $200 \mathrm{~mm}$, the electric power of $\sim 2 \mathrm{~kW}$ was required for heating the metal melt to $1500 \mathrm{~K}$.

A reliable acoustic contact between the quartz sound ducts and liquid metal was provided by applying a thin intermediate layer of boric anhydride onto their ends [6]. Because of the softening of boric anhydride at a temperature of about $750 \mathrm{~K}$, the principal measurements were started at this particular temperature. The experiments were performed under both heating and cooling of metal melt with isothermal holding at each working temperature for at least 20 minutes.

The liquid metal temperature in the measuring cell was monitored by two Chromel-Alumel thermocouples (calibration K [6]) calibrated at their location (see Fig. 1b) by the reference points of ITS90 , i.e., the solidification temperatures of gallium, tin, aluminum, and silver. Their error was $\pm 0.2 \mathrm{~K}$ at a temperature of $1000 \mathrm{~K}$ and below and $\pm 0.3 \mathrm{~K}$ at higher temperatures.

The measuring cell was located within the working chamber of the experimental setup described in [7].

Prior to the beginning of basic measurements, a sample of metal or of alloy under investigation in the form of pieces of different sizes was charged into the measuring cell. After that, the experimental setup was evacuated at vacuum of $1 \times 10^{-2} \mathrm{~mm} \mathrm{Hg}$ for an hour and then filled with high-purity helium. This procedure of flushing the inner space of the facility was repeated several times. The pressure of inert gas in the setup was finally set at a level of $\sim 0.1 \mathrm{MPa}$.

High-purity metals were employed in the experiments, namely, S00 lead to GOST (State Standard) 22861-93 and Vi00 bismuth to GOST 10928-90, the chemical composition of which according to the manufacturer is given in Table 1 . The lead-bismuth alloy of eutectic composition was prepared using the weight method by way of alloying pure lead and bismuth in vacuum. Chemical analysis of several samples of this eutectic performed in a specialized laboratory revealed that the content of lead was $44.5 \%$ by mass on the average and that of bismuth- $55.5 \%$ by mass. The error of this analysis was estimated at $\pm 0.2 \%$ by mass.

The content of metal impurities in the investigated metals was additionally determined after the basic measurements. Mass-spectrometric analyses were performed in a specialized mass-spectrometric and gaschromatographic laboratory.

These analyses revealed that the purity of $\mathrm{Pb}, \mathrm{Bi}$, and eutectic $\mathrm{Pb}-\mathrm{Bi}$ alloy hardly varied during the investigations.

Table1.Chemical composition of investigated metals

\begin{tabular}{|c|c|c|c|}
\hline \multirow{13}{*}{ 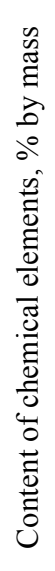 } & & Lead & Bismuth \\
\hline & $\mathrm{Fe}$ & $1 \times 10^{-5}$ & $1 \times 10^{-3}$ \\
\hline & $\mathrm{Ni}$ & $1 \times 10^{-5}$ & \\
\hline & $\mathrm{Cu}$ & $1 \times 10^{-5}$ & $1 \times 10^{-4}$ \\
\hline & $\mathrm{Zn}$ & $2 \times 10^{-5}$ & $5 \times 10^{-4}$ \\
\hline & As & $7 \times 10^{-5}$ & \\
\hline & $\mathrm{Ag}$ & $1 \times 10^{-5}$ & $2 \times 10^{-5}$ \\
\hline & $\mathrm{Cd}$ & $1 \times 10^{-5}$ & $5 \times 10^{-5}$ \\
\hline & $\mathrm{Sb}$ & $3 \times 10^{-5}$ & $2 \times 10^{-5}$ \\
\hline & $\mathrm{Hg}$ & $5 \times 10^{-5}$ & \\
\hline & $\mathrm{Tl}$ & $1 \times 10^{-5}$ & \\
\hline & $\mathrm{Pb}$ & 99.9996 & $1 \times 10^{-2}$ \\
\hline & $\mathrm{Bi}$ & $5 \times 10^{-5}$ & 99.98 \\
\hline
\end{tabular}

\subsection{Density measurements}

Highly pure gallium, indium, tin, lead and bismuth was used in this investigation. Their chemical composition is given in Table 2. The melting point of these heavy metals is indicated in the same place by data [8].

Table 2. The chemical composition, melting point and values of temperature and density both in the reference point for investigated heavy metals.

\begin{tabular}{llcccc}
\hline $\begin{array}{l}\text { Investigated } \\
\text { metal }\end{array}$ & Gallium & Indium & Tin & Lead & Bismuth \\
\hline $\begin{array}{l}\text { Chemical } \\
\text { composition } \\
\text { \% by mass }\end{array}$ & 99.99 & 99.999 & 99.99 & 99.999 & 99.99 \\
$\begin{array}{l}\text { Melting } \\
\text { point, }\end{array}$ & 302.91 & 429.74 & 505.08 & 600.61 & 544.55 \\
$\begin{array}{l}T_{\mathrm{m}}, \mathrm{K} \\
\text { Reference } \\
\text { point } T_{0}, \mathrm{~K}\end{array}$ & 303.0 & 293.2 & 293.3 & 293.2 & 293.3 \\
$\rho_{0}, \mathrm{kgm}^{-3}$ & 6096.1 & 7286.0 & 7297.1 & 11256.6 & 9804.8 \\
\hline
\end{tabular}

The method of penetrating $\gamma$-radiation was used to measure the density of heavy metals in the condensed state. It is based on the ability of atoms of the substance to interact with gamma-quanta incident on them. The attenuation of radioactive radiation during transmission through the metal studied at a given temperature was defined by the relation [9]

$I=I_{0} \exp (-\mu d \rho) B_{i}$

were $I_{0}$ and $I$ denote the intensity of incident flux of gamma-quanta and of that transmitted through the sample of investigated metal, respectively; $\mu$ is the mass coefficient of attenuation of radiation, which is dependent only on the energy of gamma-quanta and on the nuclear charge of atoms of absorbing material; $d$ is the characteristic dimension (the thickness or diameter) 
of the sample of heavy metal; $\rho$ is the density of the investigated metal; and $B_{v}$ is the build-up factor equal to the ratio of total recorded intensity to the intensity of unscattered radiation.

In present study, the sample was illuminated by a narrow beam of monochromatic gamma-radiation. In this case, the detector registered mainly the quanta, which did not interact with atoms of the substance being investigated. Therefore, the build-up factor $B_{v}$ differs little from unity.

Then the basic calculation formula of the measurement method will be written as

$\rho=\left[\ln \left(I_{0} / I\right)\right] /(\mu d)$,

and the density of investigated metal at the working temperature is determined by measuring the intensity of incident (prior to the experiments) $\gamma$-radiation and of gamma-radiation that passed through the sample (during experiments), as well as the characteristic dimension of the sample in view of thermal expansion of the crucible material.

In order to calculate the mass coefficient of attenuation of radiation, one must know the density of investigated metal in the condensed state at some single temperature or, in other words, it is necessary to have the so-called reference point. The reference density may be found by reliable experimental data available from the literature, or it may be measure in a separate experiment by other methods. In present investigation, $\rho_{0}$ of heavy metals without gallium is defined by the method of hydrostatic weighing of their samples in air and distilled water or toluene at room temperature. In so doing, the density of toluene is measured by a dilatometer method, and the density of water is found by reference data [10].

Since the melting point of gallium is intimated with the room temperature, then its reference point is measured by the method of hydrostatic weighing of a molybdenum float in the liquid gallium at the melting point. Founded values of the reference density of investigated heavy metals is given in Table 2. Their error is equal $\pm 0.05 \%$.

The method of penetrating gamma-radiation was described in more detail in [11], and the error components were successively treated in [12]. According to these estimates, the confidence error of determination of the density of heavy metals in the liquid phase was $0.2-0.4 \%$ at temperatures up to $2000 \mathrm{~K}$ and, in the solid phase, $\sim 0.4 \%$.

An ingenious setup was developed for the realization of the above-described method of measuring the density of metals in the condensed state - a hightemperature gamma-densimeter. It consisted of a heating furnace with circuits of electric supply and of temperature adjustment and measurement, a source and detector of $\gamma$-radiation, and instruments of conversion of measurement signals and output of experimental information.
The structure of the gamma-densimeter is described in detail in [13]; we deal only with some procedurally important elements.

The electric resistance furnace was made of a thin molybdenum sheet in the form of tubular heater to whose ends the voltage was applied from a single phase regulating transformer. Top and bottom guard heaters (each with autonomous electric supply) and end screens joined to them were located within the main heater; on the outside, a system of radial screens was provided. This furnace made it possible to perform measurements at temperatures up to $2000 \mathrm{~K}$. An isothermal zone about $60 \mathrm{~mm}$ high was developed in the middle part of the furnace; the temperature gradient in this zone did not exceed $10 \mathrm{~K} / \mathrm{m}$.

The source of gamma-quanta was provided by an ampoule with a ${ }^{137} \mathrm{Cs}$ isotope with an activity of 240 $\mathrm{GBq}$ or with frequency of $210^{5}$ pulse per second, and their detector - by a scintillation detector with a single crystal of NaJ. The narrow beam of $\gamma$-radiation was formed using two coaxial metallic collimators $5 \mathrm{~mm}$ in diameter, whose length was $\sim 200 \mathrm{~mm}$. The calculation revealed that, with the given beam geometry, the buildup factor differed from unity by less than $0.1 \%$.

The structure of the measuring cell is shown in Figure 2. It was a cylindrical tantalum crucible filled with the metal being investigated. The thick-walled crucible was at the same time a thermostatic block. Two pipes with dead-end bottoms were passed through the detachable lid of the crucible. Measuring thermocouples were inserted in these pipes, with two-channel alundum straws fitted onto their thermoelectrodes. The hot junctions of the thermocouples were located in the vicinity of the axis of passage of the beam of $\gamma$-quanta. In order to preclude the excessive attenuation of the radiation intensity, an annular grove was provided on the crucible, and the thickness of its walls was thereby reduced.

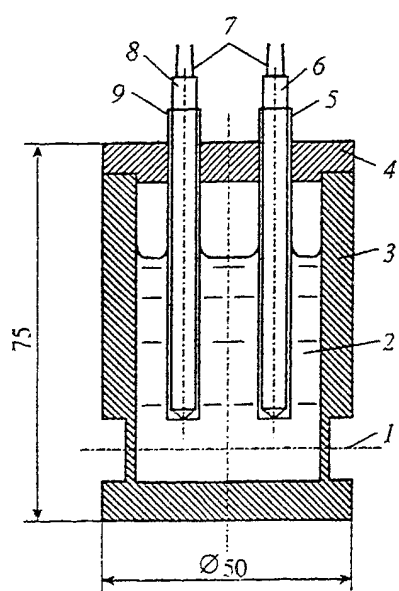

Fig. 2. Schematic diagram of the measuring cell: $1-\gamma$-quanta flux axis; 2 - investigated metal; 3 - crucible; 4 - cover; 5, 9

- protective tubes; 6,8 - alundum straws; 7 - measuring thermocouples. All dimensions are given in $\mathrm{mm}$.

The measuring cell was mounted within the heating furnace on a special support, which could be displaced in the vertical direction by means of a lifting mechanism and located in the furnace such that the 
collimator axis, the source and detector $\gamma$-radiation would coincide with the center of its isothermal zone. In addition, the cell was thoroughly adjusted, and the flux of gamma-quanta was centrally incident on the sample of investigated metal normally to the equatorial section of the crucible.

The measuring thermocouple were provided by Chromel-Alumel thermocouples at temperatures up to $1200-1300 \mathrm{~K}$ and tungsten-rhenium (5/20A) thermocouples at higher temperatures. They were additionally verified by melting points of heavy metals being investigated and by reference points of the International Temperature Scale of 1990 (ITS-90) directly in the experimental setup. In so doing, the error of measurement of the temperature of the investigated metal was estimated at $1 \mathrm{~K}$ for temperatures up to $1300 \mathrm{~K}$ and at $1-1.5 \mathrm{~K}$ for temperatures up to $1500-2000 \mathrm{~K}$.

\subsection{Viscosity measurements}

The kinematic viscosity was measured using a method based on registering the period and decrement of damping of torsional vibrations of cylindrical crucible with liquid under investigation. The values of kinematic viscosity were calculated by the formula derived by Shvidkovskii [14] as a result of solution of the inner hydrodynamic problem for low-viscous liquids such as most of liquid metals:

$v=\frac{1}{\pi}\left(\frac{\hat{E}}{\grave{I} R}\right)^{2} \frac{\left[\delta-\left(\delta_{0} / \tau_{0}\right) \tau\right]^{2}}{\tau \sigma^{2}}$

Here, $\mathrm{M}$ and $\mathrm{R}$ denote the mass of melt and the crucible radius, respectively; $\mathrm{K}$ is the moment of inertia of the suspension system; $\delta$ and $\tau$ denote the decrement of damping and the period of vibrations of the system with melt, respectively; $\delta_{0}$ and $\tau_{0}$ - the same for an empty system; and $\sigma$ is a quantity which takes into account the transmission of momentum from the crucible bottom, the values of which were determined by the method of successive approximations.

The measurements were performed in a setup, the schematic diagram of which is given in [15]. For raising the sensitivity of the viscometer, the parameters of its suspension system were optimized, namely, beryllium oxide crucibles of inside radius of $8.5 \mathrm{~mm}$ were employed, the mass of sample ranged from 30 to $60 \mathrm{~g}$, the moment of inertia of the suspension system was

$8.58 \cdot 10^{-4} \mathrm{~kg} \mathrm{~m}{ }^{2}$, the diameter of nichrome filament was $0.24 \mathrm{~mm}$, and the period of vibrations was about $3.5 \mathrm{~s}$. The foregoing physical and geometric parameters of the suspension system provided for the feasibility of the conditions within which formula (1) was derived,

$H \geq 1.85 R$, $y=\frac{2 \pi R^{2}}{\tau v} \geq 100$,

where $\mathrm{H}$ is the height of sample.

The viscosity is determined in a process of indirect measurements and calculated as a function of a number of directly measured quantities. Svidkovskii's equation (6) sets a complex dependence of kinematic viscosity on various parameters determined experimentally. The maximal contribution to the error of measurement of kinematic viscosity is made be the error of determination of decrement of damping of vibrations. For raising the accuracy of its determination, we used an ingenious system of registering the amplitude. The oscillation of light beam reflected from the mirror of the suspension system onto a transparent rule was registered by a video camera. Then, following the computer processing of the video image, the least squares method was used for approximating by linear function the oscillation number dependence of amplitude logarithm. The decrement is proportional to the angular coefficient of this function. The error of its determination was calculated by the standard formula of the least squares method. This error is between 1 and $2 \%$ for different samples and temperatures.

Therefore, the overall relative error of determination of kinematic viscosity at $p=0.95$ does not exceed $2.5 \%$.

The random component of error alone is of importance from the standpoint of analyzing the reliability of various anomalies on the temperature dependences of viscosity. In our case, it is very close to the error of determination of the decrement of damping of vibrations, i.e., it does not exceed $2 \%$ at $p=0.95$.

\section{Measurement results and their analysis}

\subsection{Ultrasound velocity}

The temperature dependencies of ultrasound velocity $a$ for pure lead, bismuth and lead-bismuth eutectic have been measured. Since these items hold much promise as coolants for fast neutron reactors, greater attention was paid to absolute values of $a$. Two experiments have been conducted with lead and bismuth, and for the leadbismuth eutectic alloy the temperature dependence of ultrasound velocity has been investigated three times. As a rule, more thorough measurements were conducted at cooling, though experiments at heating have also been performed. The composition and characteristics of the conducted experiments for measuring the equilibrium values of ultrasound velocity including the number of experimental points are given in Table 3 .

Each experimental point was received in isothermal conditions (the accuracy of temperature maintenance was $\pm 0,3 \mathrm{~K}$ ) at the exposure of no less than 20 minutes. At this temperature the received value of the ultrasound velocity is on average the result of twenty measurements at the acoustic base of $5 \mathrm{~mm}$ (the estimated systematic error of measurement in these 
conditions is $0.03 \%$ ). The random error does not exceed $0.3 \%$.

Table 3. Basic conditions of measurements of the density and ultrasound velocity of heavy metals in the condensed

\begin{tabular}{|c|c|c|c|c|c|}
\hline 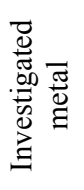 & 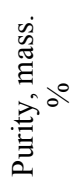 & 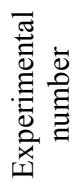 & 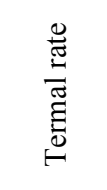 & 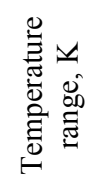 & 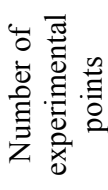 \\
\hline \multirow{3}{*}{ ت્ّ } & \multirow{3}{*}{ 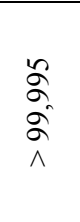 } & 1 & cooling & $\begin{array}{c}944- \\
694\end{array}$ & 13 \\
\hline & & \multirow{2}{*}{2} & heating & $\begin{array}{c}1001- \\
1378\end{array}$ & 5 \\
\hline & & & cooling & $\begin{array}{c}1316- \\
606 \\
\end{array}$ & 16 \\
\hline \multirow{3}{*}{ 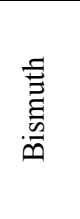 } & \multirow{3}{*}{$\begin{array}{l}\circ \\
\text { } \\
\text { aे } \\
\wedge\end{array}$} & 1 & cooling & $\begin{array}{c}1376- \\
546\end{array}$ & 39 \\
\hline & & \multirow{2}{*}{2} & heating & $\begin{array}{l}760- \\
1380 \\
\end{array}$ & 52 \\
\hline & & & cooling & $\begin{array}{c}1194- \\
720\end{array}$ & 26 \\
\hline \multirow{5}{*}{ 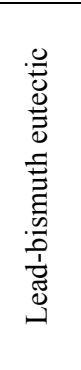 } & \multirow{5}{*}{ 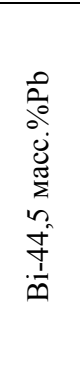 } & \multirow{2}{*}{1} & heating & $\begin{array}{c}784- \\
1374\end{array}$ & 7 \\
\hline & & & cooling & $\begin{array}{c}1404- \\
401 \\
\end{array}$ & 30 \\
\hline & & 2 & cooling & $\begin{array}{c}1277- \\
404\end{array}$ & 22 \\
\hline & & \multirow{2}{*}{3} & heating & $\begin{array}{c}975- \\
1370 \\
\end{array}$ & 6 \\
\hline & & & cooling & $\begin{array}{c}1322- \\
406\end{array}$ & 20 \\
\hline
\end{tabular}

Figure 3 shows together all the curves of dependence of ultrasound velocity on temperature built according to the experimental data received in the present work.

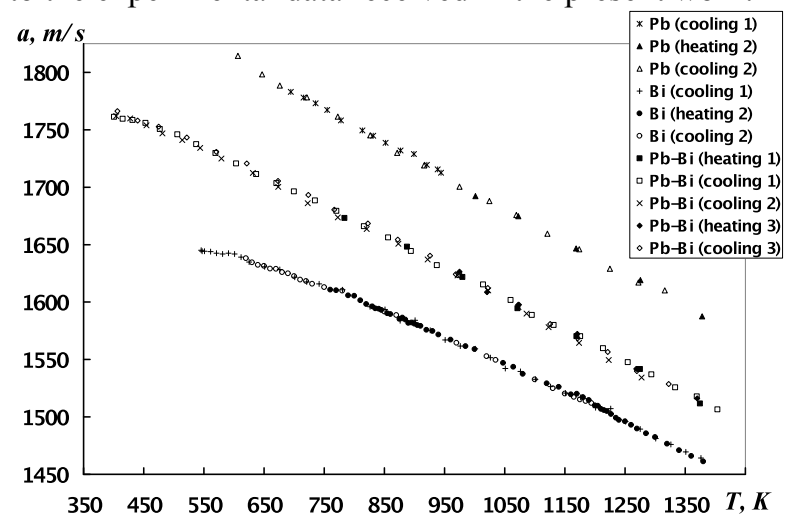

Fig. 3. Temperature dependences of ultrasound velocity in liquid lead, bismuth and their eutectic alloy.

It is known that the temperature dependence of ultrasound velocity is linear for most liquid metals and can be interpolated by the equation:

$a(T)=a_{L}-\beta\left(T-T_{L}\right)$,

where $T_{L}$ is melting temperature, $\beta=d a / d T-$ is the temperature coefficient of ultrasound velocity, $a_{L}$ is the velocity of sound at temperature $T_{L}$.

However, for liquid bismuth and lead-bismuth eutectic the experimental curves cannot be described well by one linear function over the whole temperature range under investigation (Fig. 3). Therefore, their temperature dependence of ultrasound velocity was interpolated with the help of the least-squares method by a polynomial approximant by the positive integral powers of the absolute temperature

$$
a(T)=a_{0} T^{0}+a_{1} T^{1}+a_{2} T^{2}+a_{3} T^{3}+\ldots,
$$

where $a$ is measured in $\mathrm{m} \mathrm{s}^{-1}$, and $T$ is measured in degrees Kelvin according to ITS-90. The optimal number of the parameters of the polynomial approximant (8) was determined with the help of Fisher's statistical test. The number and values of the coefficients of this equation and of their mean-square error $\Delta a_{0}, \Delta a_{1}, \Delta a_{2}, \ldots$ at $95 \%$ confidence level are given in Table 4.

The relative deviation $\gamma_{a}=\left(a_{3}-a_{\mathrm{a}}\right) / a_{\mathrm{a}} \cdot 100$ of the experimental data received by us from $a_{\mathrm{a}}$ calculated by the approximate equation (8) is given in Fig. 4. Its mean-square value does not exceed $0.1 \%$ with the random measurement error being no higher than $0.3 \%$.

Figure 5 shows the temperature dependences of the velocity of sound in molten lead, bismuth and leadbismuth eutectic according to the data found in works by other authors and according to the results of the present work. One can see that the results of highfrequency measurements $(>10 \mathrm{MHz})$ are in good agreement within the confidence errors. At the same time, the values of ultrasound velocity obtained at low frequencies $[14,18]$ lie above the results obtained in the present work and above the results of other measurements at higher frequency.

Comparing the experimental data about the ultrasound velocity for the mixture calculated by Kudryavtsev's interpolation formula presents a certain interest. For a binary system this formula looks like $a_{P b-B i}^{2}=w_{P b} a_{P b}^{2}+w_{B i} a_{B i}^{2}$, where $w_{P b}$ and $w_{B i}$ are weight fractions of lead and bismuth in the alloy, and $a_{P b}$ and $a_{B i}$ are the experimental values of ultrasound velocity in pure lead and bismuth. The approximate value of ultrasound velocity in lead-bismuth eutectic $a_{P b-B i}$ calculated by this formula is also given in Fig. 5 . One can see that the calculated value of ultrasound velocity coincides with the experimental one within the measurement error.

Table 4. Values of the coefficients of approximate equation (8) and their mean-square error.

\begin{tabular}{|c|c|c|c|c|c|c|c|}
\hline$a_{0}$ & $\Delta a_{0}$ & $a_{1}$ & $\Delta a_{1}$ & $a_{2}$ & $\Delta a_{2}$ & $a_{3}$ & $\Delta a_{3}$ \\
\hline \multicolumn{2}{|c|}{$\mathrm{m} / \mathrm{s}$} & \multicolumn{2}{|c|}{$\mathrm{m} /(\mathrm{s} \cdot \mathrm{K})$} & \multicolumn{2}{|c|}{$10^{-3} \mathrm{~m} /\left(\mathrm{s} \cdot \mathrm{K}^{2}\right)$} & \multicolumn{2}{|c|}{$10^{-6} \mathrm{~m} /\left(\mathrm{s} \cdot \mathrm{K}^{3}\right)$} \\
\hline \multicolumn{8}{|c|}{ Lead } \\
\hline $\begin{array}{l}198 \\
4,44\end{array}$ & 1,60 & $\begin{array}{c}- \\
0,288 \\
36\end{array}$ & $\begin{array}{c}0,001 \\
66\end{array}$ & - & - & - & - \\
\hline \multicolumn{8}{|c|}{ Bismuth } \\
\hline $\begin{array}{c}171 \\
7,48\end{array}$ & 0,50 & $\begin{array}{c}- \\
0,085 \\
83\end{array}$ & $\begin{array}{c}0,001 \\
07\end{array}$ & $\begin{array}{c}- \\
0,072 \\
98\end{array}$ & $\begin{array}{c}0,000 \\
55\end{array}$ & - & - \\
\hline \multicolumn{8}{|c|}{ Lead-bismuth eutectic } \\
\hline $\begin{array}{c}182 \\
0,83\end{array}$ & 3,04 & $\begin{array}{c}- \\
0,073 \\
67\end{array}$ & $\begin{array}{c}0,011 \\
44\end{array}$ & $\begin{array}{c}- \\
0,188 \\
96\end{array}$ & $\begin{array}{c}0,013 \\
35\end{array}$ & $\begin{array}{c}0,058 \\
63\end{array}$ & $\begin{array}{c}0,004 \\
90\end{array}$ \\
\hline
\end{tabular}



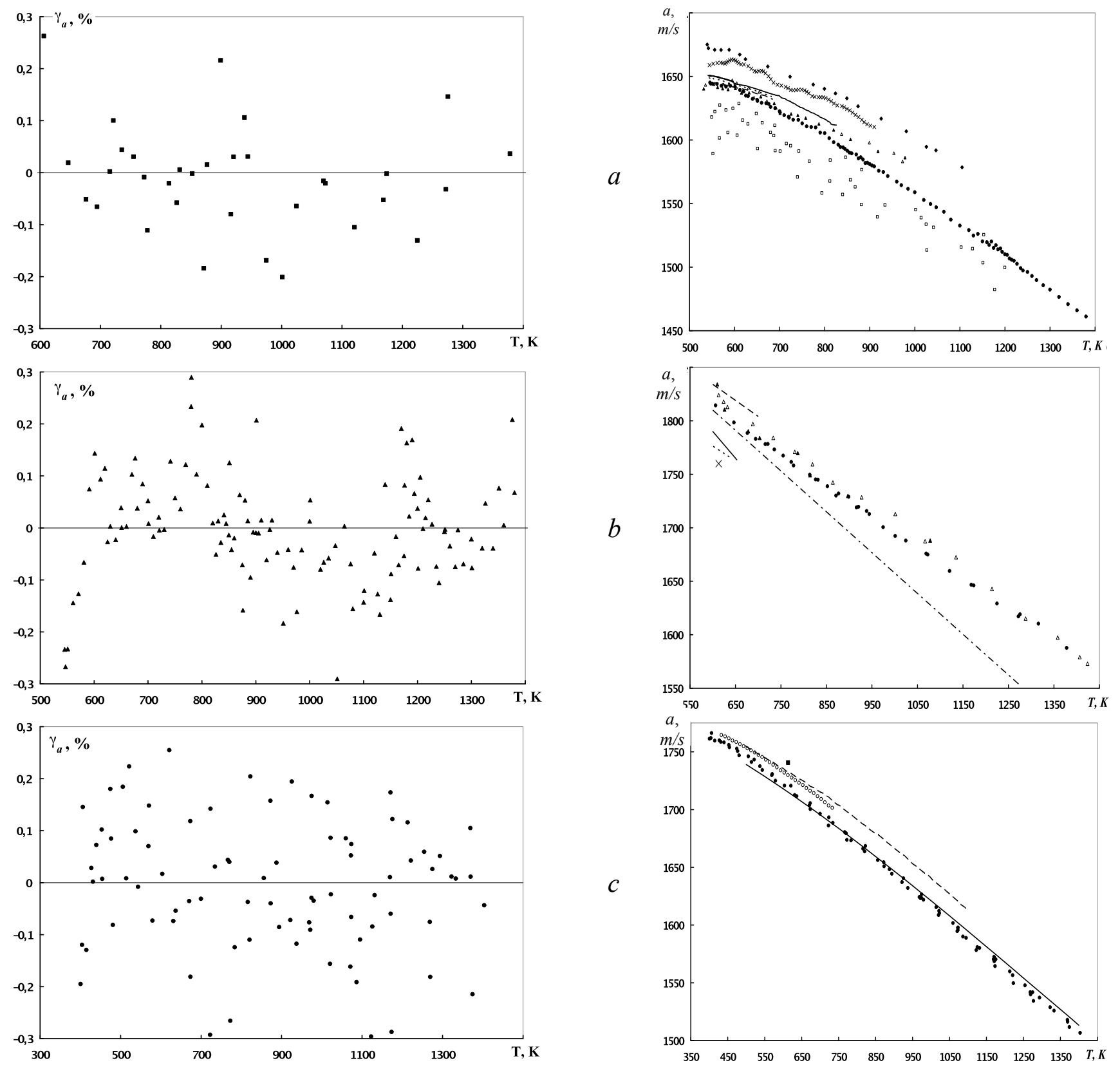

Fig. 4. Relative deviation of the experimental data about the velocity of sound in molten lead, bismuth and leadbismuth eutectic received in the present work from the data calculated using the approximate equation (8): $\mathbf{-}$ - in lead melt; $\boldsymbol{\Delta}$ - in bismuth melt; $\bullet$ - in lead-bismuth eutectic melt. liquid:

Fig. 5. Temperature dependences of ultrasound velocity in

$a$ - bismuth $\left(\bullet-\right.$ all our data, $\frac{-}{-[15],--~-~-~[16],----~}$ [17], $\mathrm{x}-[18], \square-[19],-[14], \boldsymbol{\Delta}-(31,9 \mathrm{MHz})[6], \Delta-$ (53,1 MHz) [6]);

$b-$ lead $(\bullet-$ all our data, $--[20],----[21,22],----$

$\left.[23,24], \mathrm{x}-[25], \quad----_{-}-[26],, \boldsymbol{\Delta}-[18], \Delta-[27]\right)$;

$c$ - lead-bismuth eutectic $(\bullet-$ all our data, $\circ-[28], \mathbf{\square}-[22]$,

$-----[29],--$ calculations according to

Kudryavtsev's interpolation formula) 


\subsection{Density}

Basic characteristics of carried out experiments are given in Table 5, where the temperature is given by the ITS-90. As a rule, these measurements were performed for the solid phase in the heating regime, and for the liquid phase in the cooling regime.

Table 5. Basic conditions of measurements of the density of heavy metals in the condensed state.

\begin{tabular}{|c|c|c|c|}
\hline $\begin{array}{c}\text { Investigate } \\
\mathrm{d} \\
\text { metal }\end{array}$ & $\begin{array}{c}\text { Aggregat } \\
\text { e state }\end{array}$ & $\begin{array}{c}\text { Temperatur } \\
\text { e range, } \mathrm{K}\end{array}$ & $\begin{array}{l}\text { Number of } \\
\text { experiment } \\
\text { al points }\end{array}$ \\
\hline Gallium & $\begin{array}{l}\text { Liquid } \\
\text { phase }\end{array}$ & $307-1874$ & 143 \\
\hline Indium & $\begin{array}{l}\text { Solid } \\
\text { phase } \\
\text { Liquid } \\
\text { phase }\end{array}$ & $\begin{array}{l}332-429 \\
432-1864\end{array}$ & $\begin{array}{c}29 \\
232\end{array}$ \\
\hline Tin & $\begin{array}{l}\text { Solid } \\
\text { phase } \\
\text { Liquid } \\
\text { phase }\end{array}$ & $\begin{array}{l}365-503 \\
506-1936\end{array}$ & $\begin{array}{c}33 \\
119\end{array}$ \\
\hline Lead & $\begin{array}{l}\text { Solid } \\
\text { phase } \\
\text { Liquid } \\
\text { phase }\end{array}$ & $\begin{array}{l}368-597 \\
604-1703\end{array}$ & $\begin{array}{c}30 \\
100\end{array}$ \\
\hline Bismuth & $\begin{array}{l}\text { Solid } \\
\text { phase } \\
\text { Liquid } \\
\text { phase }\end{array}$ & $\begin{array}{l}337-539 \\
546-1505\end{array}$ & $\begin{array}{c}60 \\
207\end{array}$ \\
\hline
\end{tabular}

The experimental data on the density for solid and liquid phases of each investigated heavy metals were treated separately from one another by least squares method. The approximating equation was provided by a polynomial in powers of temperature

$$
\rho=a_{0}+a_{1} T+a_{2} T^{2}+a_{3} T^{3}+\ldots,
$$

where $\rho$ is the density of investigated metal in $\mathrm{kg} \mathrm{m}^{-3}$, and $T$ is the absolute temperature in K by the ITS -90 . The coefficients of the approximating equation (9), which were found by the regression-statistical analysis of the results of this processing using the Fisher's test [30], are given in Table 6, and the graphic interpretation of this equation is shown on Figure 6. The mean-square deviation of the experimental points of the present work from approximating equation (9) did not exceed $0.2 \%$ for the solid phase and $0.1 \%$ for the liquid phase.

The results of carried out experiments agree well with available in the literature reference data on the density of heavy metals in the condensed state (see, for example, [31,32]).

Also of great important from the standpoint of practical application is the variation (jump) of the density of investigated metals during melting, which was determined by the formula

$$
\Delta \rho=\left(\rho_{m}^{s}-\rho_{m}^{l}\right) / \rho_{m}^{s},
$$

where $\rho_{m}^{s}$ and $\rho_{m}^{l}$ denote the density of heavy metals in the solid and liquid phases at the melting temperature, respectively. Their values are determined on the approximating equation (9). The results of the calculation on the formula (10) are given in Table 7. As is obvious clear from Table 7, the calculated data on $\Delta \rho$ for investigated heavy metals are practical coincided with their recommended values [33].

Table 6. Coefficients of the approximating equation (9) for the

density of investigated heavy metals in the condensed phase.

\begin{tabular}{|c|c|c|c|c|c|}
\hline $\begin{array}{c}\mathrm{Me} \\
\text { tal }\end{array}$ & $\begin{array}{c}\text { Aggregat } \\
\text { e state }\end{array}$ & $a_{0}$ & $a_{1}$ & $a_{2}$ & $a_{3}$ \\
\hline $\mathrm{Ga}$ & $\begin{array}{c}\text { Liquid } \\
\text { phase }\end{array}$ & 6335.59 & -0.84737 & 0.21034 & -0.04933 \\
\hline $\mathrm{In}$ & $\begin{array}{c}\text { Solid } \\
\text { phase } \\
\text { Liquid } \\
\text { phase }\end{array}$ & 7371.17 & -0.91624 & - & - \\
\hline $\mathrm{Sn}$ & $\begin{array}{c}\text { Solid } \\
\text { phase }\end{array}$ & 7467.35 & -0.58101 & - & -0.04405 \\
& $\begin{array}{c}\text { Liquid } \\
\text { phase }\end{array}$ & 7382.37 & -0.84820 & 0.11117 & -0.01394 \\
\hline $\mathrm{Pb}$ & $\begin{array}{c}\text { Solid } \\
\text { phase } \\
\text { Liquid } \\
\text { phase }\end{array}$ & 11503.70 & -0.84336 & - & - \\
\hline $\mathrm{Bi}$ & $\begin{array}{c}\text { Solid } \\
\text { phase } \\
\text { Liquid } \\
\text { phase }\end{array}$ & 11200.23 & -0.66285 & 0.55397 & -0.17453 \\
\hline
\end{tabular}

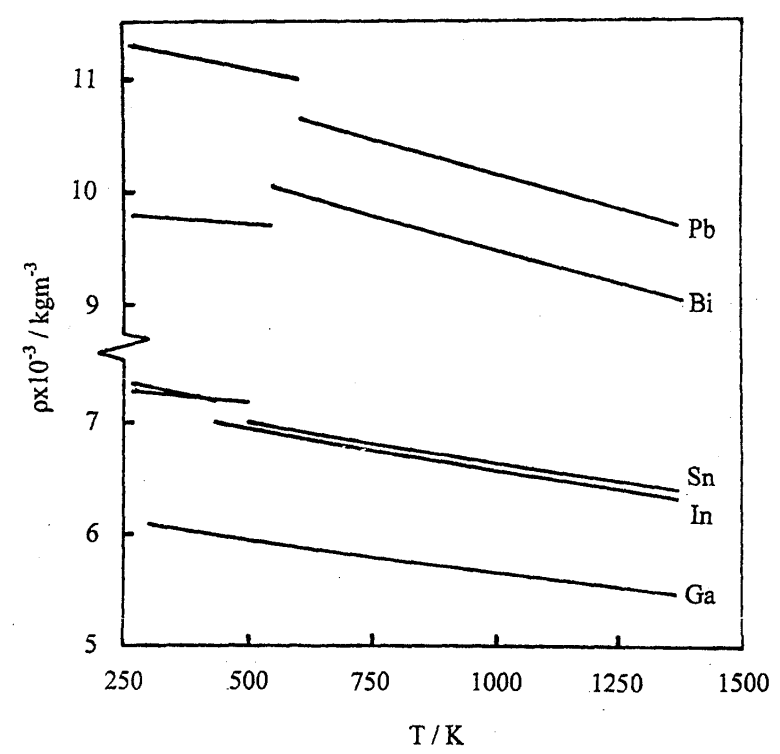

Fig. 6. The temperature dependence of the density of investigated heavy metals in the condensed state. 
Table 7. The discontinuous change of the density during melting for investigated heavy metals.

\begin{tabular}{|c|c|c|c|c|c|}
\hline $\begin{array}{c}\text { Investigated } \\
\text { metal }\end{array}$ & $\mathrm{Ga}$ & $\mathrm{In}$ & $\mathrm{Sn}$ & $\mathrm{Pb}$ & $\mathrm{Bi}$ \\
\hline $\begin{array}{c}\text { Present } \\
\text { work }\end{array}$ & -3.20 & 2.28 & 2.70 & 3.25 & -3.45 \\
\hline $\begin{array}{c}\text { Reference } \\
\text { data [32] }\end{array}$ & -3.23 & $2.25 \pm$ & 2.70 & 3.30 & -3.42 \\
\pm 0.05 & 0.15 & \pm 0.05 & \pm 0.25 & \pm 0.10 \\
\hline
\end{tabular}

\subsection{Kinematic viscosity}

The temperature dependences of kinematic viscosity received at heating and subsequent cooling of the samples are given in Fig.7.

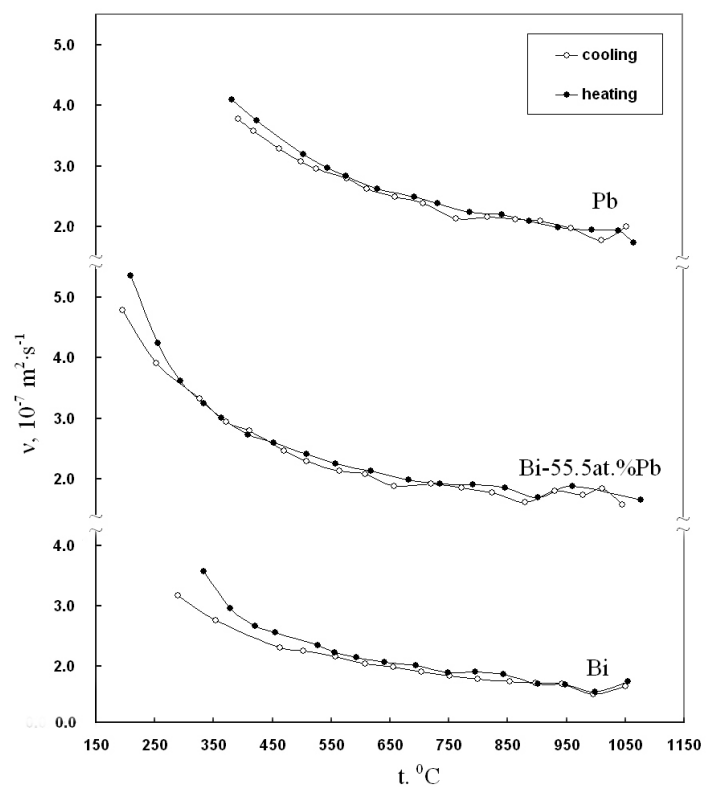

Fig. 7. Temperature dependences of kinematic viscosity of liquid lead, bismuth and their eutectic alloy $(44.5 \%$ by mass $\mathrm{Pb}+55.5 \%$ by mass $\mathrm{Bi}$ [1]) obtained at heating ( ) and subsequent cooling ( ) of the samples.

During their analysis one notices first of all the branching of heating and cooling curves $v(\mathrm{t})$ (hysteresis of viscosity) for liquid bismuth and the eutectic alloy $(44.5 \%$ by mass $\mathrm{Pb}+55.5 \%$ by mass Bi [1]). Since the above-stated effect does not occur in liquid lead, and the branching point of the cooling and heating curves is close to the temperature of the first kink on the temperature dependence of ultrasound velocity in liquid bismuth (about $600 \mathrm{~K}$, see Fig. 3), the authors are inclined to explain this effect by a structural change in liquid bismuth near the stated temperature.

Assuming that the values received at cooling correspond to the thermodynamically stable equilibrium state of the melt, we calculated the values of kinematic viscosity for the investigated samples at fixed temperatures by quadratic interpolation (see Table 8).
Table 8. Values of kinematic viscosity of liquid lead, bismuth and their eutectic alloy at fixed temperatures, $\mathrm{m}^{2} \mathrm{~s}^{-1}$.

\begin{tabular}{|c|c|c|c|}
\hline Melt & $\mathrm{Pb}$ & $55,5 \% \mathrm{Bi}$ & $\mathrm{Bi}$ \\
\hline $350{ }^{\circ} \mathrm{C}$ & 3,63 & 3,08 & 2,64 \\
\hline $450{ }^{\circ} \mathrm{C}$ & 3,28 & 2,77 & 2,43 \\
\hline $550^{\circ} \mathrm{C}$ & 2,96 & 2,49 & 2,24 \\
\hline $650{ }^{\circ} \mathrm{C}$ & 2,67 & 2,23 & 2,07 \\
\hline $750^{\circ} \mathrm{C}$ & 2,41 & 2,00 & 1,91 \\
\hline $850^{\circ} \mathrm{C}$ & 2,17 & 1,80 & 1,76 \\
\hline $950{ }^{\circ} \mathrm{C}$ & 1,96 & 1,61 & 1,62 \\
\hline $1050^{\circ} \mathrm{C}$ & 1,77 & 1,45 & 1,50 \\
\hline $1100^{\circ} \mathrm{C}$ & 1,68 & 1,37 & 1,44 \\
\hline
\end{tabular}

\section{Conclusion}

Thus, in the present work temperature dependences of ultrasound velocity, density and kinematic viscosity of heavy liquid-metal coolants (HLMC) perspective for using in new nuclear reactors, such as gallium, indium, tin, lead, bismuth and reciprocal binary lead-bismuth alloy of eutectic composition $(44.5 \%$ by mass $\mathrm{Pb}+$ $55.5 \%$ by mass $\mathrm{Bi}[1]$ ) have been studied for the first time over a wide temperature range using samples of identical chemical composition. The received data can be useful in calculating hydrodynamic regimes of coolants flow in reactor circuits and in choosing the optimal parameters of these devices.

\section{Acknowledgment}

This study was supported by the Russian Foundation for Basic Research (project nos. 09-08-00040a, 07-080589a, 09-08-01212 and 10-08-00802).

\section{References}

1. T.B. Massalski, Binary Alloy Phase Diagrams, Ed., Metals Park, Ohio: American Society for Metals, 1 (1987)

2. H. Preston-Thomas, Metrologia, 27 1, 3(1990)

3. P.L. Kirillov, M.I. Terent'eva, and N. B. Deniskina, Teplofizicheskie svoistva materialov yadernoi tekhniki. (Moscow: Izd.AT,2007)

4. Handbook on Lead-Bismuth Eutectic Alloy and Lead Properties, Materials Compatibility, ThermalHydraulics and Technologies, Karlsruhe: Forschungszentrum Karlsruhe, 2007.

5. V. M. Glazov, S. G. Kim, and G. K. Mambeterzina, Zavod. Lab., 57 8, 45 (1991).

6. K.S. Guk, Molecular Acoustics of Liquid Semimetals and Semiconductors, Doctoral (Chem.) 
Dissertation, Moscow: Inst. of General and Inorganic Chemistry, Russ. Acad. Sci. (IONKh RAN), 1991.

7. P.S.Popel, D.A.Yagodin, A.G.Mozgovoj and M.A.Pokrasin, An Experimental Investigation of the Velocity of Sound in Molten Lead and Bismuth and in Their Reciprocal Eutectic Alloy at High Temperatures. High Temperature, 48 2, 181-187 (2010)

8. L. V. Gurvich, I.V. Veits, V.A. Medvedev, G.A. Khachkurusov, V.S. Yungman, G.A.Bergman, V.F. Baibuz, V.S. Iorish, G. N. Yurkov, S.I. Gorbov et al., Termodinamicheskie Svoistva Individualnykh Veshchestv (Thermodynamic Properties of Individual Substances) 2 (Moscow: Science, 1979) (in Russian) 9. H. Hart, Flussigkeitsdichtemessung mit Hilfe von Kernstralung (Berlin: Springer, 1972)

10. A.A. Aleksandrov and M.C. Trakhtengerts, Voda. Plotnost pri Atmosfernom Davlenii i Temperaturakh ot 0 do $100^{\circ} \mathrm{C}$ (The Water. The Density at the Atmospheric Pressure and Temperatures from 0 up to $100^{\circ} \mathrm{C}$ ) (Moscow: Standards, 1978) (in Russian)

11. S.V. Stankus, Issledovanie po Gidrodinamike $i$ Teploobmenu (The Investigation on the Hydrodynamics and Heat Exchange) (Novosibirsk: Institute of Thermophysics, Siberian Division of the USSR Academy of Sciences. 1980) 113 (in Russian) 12. S.V. Stankus, Gamma-Metod v Metallurgicheskom Experimente (Gamma-Method in the Metallurgical Experiment) (Novosibirsk: Institute of Thermophysics, Siberian Division of the USSR Academy of Sciences, 1981) 71 (in Russian)

13. A.S. Basin, A.B. Baginskii, Ya.L. Kolotov, S.V. Stankus, Gamma-Metod v Metallurgicheskom Experimente (Gamma-Method in the Metallurgical Experiment) (Novosibirsk: Institute of Thermophysics, Siberian Division of the USSR Academy of Sciences, 1981) 11 (in Russian)

14. M.B. Gitis, I.G. Mihailov, Rasprostranenie zvuka $v$ zidkich metallach. Acusticheskii jurnal, 2 12, 181 (1966) (in Russian).

15. E.G. Pashuk, B.P. Pashaev, Issledovanie skorosti ultrazvuka $v$ metallicheskich rasplavach $v$ shirokom intervale temperatur, Teplofizika visokich temperatur, 18 2, 312 (1980)

16. R.T. Smith, G.M. Webber, E. Young, Adv. Phys., 16 63, 515 (1967)

17. J.E. Hill, A.L. Ruoff, Chem. Phys., 43 6, 2150 (1966)

18. V.M. Glazov, S.G. Kim, Oszillyazii skorosti ultrazvuka $v$ electronnich rasplavach pri ich nagrevanii, Dokl. Akad. Nauk SSSR, 273 2, 371(1983)

19. L.A. Pronin, S.I. Filippov, Sostoyanie jidkich metallov na osnove acusticheskich dannich, Izv. Vyssh. Uchebn. Zaved. Chern.Metall., 5, 12 (1963)

20. O.I. Kleppa, Ultrasonic velocities of sound in some liquid metals. Adiabatic and isothermal compressibility of liquid metals at their melting points. J. Chem. Phys., 18, 1331 (1950)

21. I.G. Polozkii, V.F. Taborov, Z.P. Chodov, Ustanovka dlya izmerenia skorosti ultrazvuka $v$ jidkich metallich. Acusticheskii jurnal., 5 2, 202 (1958) 22. L. Chodov, Skorost ultrazvuka v rasplavach dvoinich metallicheskich sistem evtekticheskogo tipa. Fizika metallov I metallovedenie, 10 5, 772(1960)

23. R. B. Gordon. Velocity of sound in liquid lead tin alloys. Phys. Chem. Proc. Metall., 1 7, 461-468 (1958)

24. B. Gordon, Propagation of sound in liquid metals. The velocity of lead and tin. Acta Met., 7, 1, 1-7 (1959)

25. K. G. P1ass, Ultraschallmessungen in Metallen im geschmolzenen Zustand und beim erstarren. Akusts. Beihefte, 13 1, 240-241 (1963)

26. L.A. Pronin, S.I. Filippov, Sostoyanie jidkich metallov na osnove acusticheskich dannich, Izv, Vyssh. Uchebn. Zaved. Chern.Metall, 5, 10-18 (1963)

27. Miyuki Hayashi, Hirokage Yamada, Naozumi Nabeshima, and Kazuhiro Nagata, Temperature Dependence of the Velocity of Sound in Liquid Metals of Group XIV International Journal of Thermophysics, 28 1, 83-96 (2007)

28. R. Kazys, A. Voleisis, R. Sliteris, L. Mazeika, P. Kupschus and H.A. Abderrahim, Development of ultrasonic sensors for operation in a heavy liquid metal. IEEE Sensors Journal, 6 5, 1134-1143 (2006)

29. V. I. Stremousov, B.A. Solomin, Skorost zvuka v troinoi metallicheskoi sisteme Bi-Pb-Sn. Zh. Fiz. Khim., 498 (1975)

30. D.J. Hudson, Statistics (Geneva: CERN, 1964)

31. B.P. Pashaev, D.K. Palchaev, E.G. Pashchuk and V.G. Revelis, Obzory po Teplofizicheskim Svoistvam Veshchestv, 31 (1982) (in Russian)

32. N. Iida and R.I.L. Guthrie, The Physical Properties of Liquid Metals (Oxford: Clarendon Press, 1988)

33. S.V. Stankus, Izmenenie Plotnosti Elementov pri Plavlenii (The Variation of the Density of Elements in Melting) (Novosibirsk: Institute of Thermophysics, Siberian Division of the USSR Academy of Sciences, 1991) (in Russian) 